DOI: https://doi.org/10.32839/2304-5809/2021-4-92-60

УДК 347.948

Соловйова Г.М.

Харківський науково-дослідний експертно-криміналістичний центр Міністерства внутрішніх справ України

\title{
МЕТОДИ ТА ЗАСОБИ ПРОВЕДЕННЯ ТОВАРОЗНАВЧОЇ ЕКСПЕРТИЗИ ЮВЕЛІРНИХ ВИРОБІВ
}

Анотація. У статті вивчено проблематику методів та засобів проведення товарознавчої експертизи ювелірних виробів. Досліджено законодавчу базу, яка регулюе експертизу ювелірних виробів та їх складових. 3'ясовано особливості класифікації ювелірних виробів у державних класифікаторах. Вивчено методику товарознавчої експертизи ювелірних виробів відповідно до етапів її проведення. Виявлено базові методи проведення товарознавчої експертизи ювелірних виробів. З'ясовано значення умови збереження оригінального стану товару на проведення експертизи. З’ясовано критерії дослідження вставок 3 дорогоцінних каменів у ювелірних виробах та перелік інструментів та засобів, необхідних для цього. Вивчено можливості та потенційні вигоди від залучення експертів з суміжних галузей для експертизи ювелірних виробів та роль експерта-товарознавця у такому дослідженні. Досліджено базові види дедектів, характерних для ювелірних виробів, які потенційно можуть бути нанесені товару в процесі експлуатації або виготовлення. Ключові слова: товарознавча експертиза, ювелірні вироби, дорогоцінні метали, дорогоцінне каміння, дефекти, методологія.

Soloviova Halyna

Kharkiv Scientific Research Forensic Center of the Ministry of Internal Affairs of Ukraine

\section{METHODS AND MEANS OF CONDUCTING COMMODITY EXPERTISE OF JEWELRY}

Summary. The article examines the problems of methods and means of conducting commodity expertise of jewelry. The legislative framework regulating the expertise of jewelry and its components is studied, namely the Order of the Ministry of Finance of Ukraine "on approval of instructions on the procedure for branding jewelry and household products made of precious metals". The features of jewelry classification in state classifiers, namely in the Unified purchasing dictionary and the state classifier 016:2010, are clarified. The main product groups corresponding to the "jewelry" category have been identified. The methodology of commodity expertise of jewelry was studied in accordance with the stages of its implementation, including: Gemological expertise, assay expertise, technological expertise, art expertise. The specifics of conducting each type of expert examination are clarified. Basic methods of conducting commodity expertise of jewelry are revealed. The basic methods are: organoleptic, instrumental, calculation, express method and cost method. The significance of the condition for preserving the original condition of the product for conducting an expert examination, selecting methods and means of research is revealed. The tools for conducting an expert examination are identified, and special attention is paid to the possibilities of using detectors and electrolysis to determine the physical and chemical characteristics of jewelry without violating their integrity. The criteria for studying inserts made of precious stones in jewelry and the list of tools and tools necessary for this are clarified. The possibilities of using detectors, X-ray spectral, x-ray luminescent methods and optical infrared spectroscopy to determine the elemental composition of stone are investigated. The possibilities and potential benefits of attracting experts from related industries for jewelry expertise and the role of a commodity expert in such research were explored. The specifics of using the comparative method and the reduction coefficient for determining the cost of a product are clarified. The basic types of defects characteristic of jewelry that can potentially be caused to the product during operation or manufacturing are studied.

Keywords: commodity expertise, jewelry, precious metals, precious stones, defects, methodology.

$\Pi$ остановка проблеми. Динамічний розвиток світового ринку товарів характерний швидким розширенням груп товарів та появою нових. Збільшуеться також і кількість виробів, які $є$ аналогами для тих, що існували раніше. Прикладом цього є ювелірні вироби, які з плином часу почали виготовляти 3 різних металів та 3 використанням ряду вставок, список яких постійно збільшується. Проте часто застосування товарів чи матеріалів-аналогів відбувається 3 порушенням технології виробнищтва або для підробки оригінальних товарів. Водночас ювелірні вироби є групою товарів, які можуть тією чи іншою мірою зберігати свою цінність незалежно від свого технічного стану та наявності дедектів. Необхідністю дослідження проблематики товарознавчої експертизи ювелірних виробів зумовлено написання ціеї статті.
Аналіз останніх досліджень і публікацій. Дослідженням методів і засобів проведення товарознавчої експертизи ювелірних виробів займались вітчизняні та іноземні науковщі, серед яких Г. Н. Айлова, М. П. Васильєва, I. А. Петренко, та інші. В. А. Поваляева вивчала можливості дослідження ювелірних виробів за допомогою сучасного обладнання, Г. Д. Кобищан досліджував проблематику ідентифікації ювелірних товарів, а В. А. Пірікович з'ясовувала особливості товарознавчої характеристики асортименту ювелірних особистих прикрас.

Виділення не вирішених раніше частин загальної проблеми. Проблематика застосування методів та засобів проведення товарознавчої експертизи ювелірних виробів все ще вимагає комплексного дослідження. Перш за все цю 
тему варто розглянути 3 урахуванням особливостей самої експертизи, а саме залучення до дослідження інших експертів, вимоги збереження оригінального стану виробу тощо. Окрему увагу варто звернути на можливості застосування органолептичного та інструментального методів на різних етапах дослідження.

Виклад основного матеріалу. Товарознавча експертиза ювелірних виробів є одним 3 найнадійніших джерел інформації для доказової бази у судовому процесі. Тому на державному рівні цьому питанню приділено велику увагу, зокрема, в контексті законодавства та класифікації. Процес експертизи ювелірних виробів регулюеться Наказом Міністерства фрінансів України «Про затвердження Інструкції про порядок здійснення клеймування ювелірних та побутових виробів 3 дорогоцінних металів, про проведення випробування та експертиз дорогоцінних металів, виробів з них, вставок дорогоцінного каміння, музейних предметів, які містять дорогоцінні метали та дорогоцінне каміння, відбитків державних пробірних клейм» [5]. Документ містить положення, що регулюють експертизу в цілому та їх складових елементів (дорогоцінних металів, каміння, виробів з них, пробірних клейм, тощо).

Ювелірні вироби мають досить широку класифрікацію відносно інших груп споживчих товарів. Відповідно до Єдиного закупівельного словника ДК 021:2015 ювелірні вироби знаходяться в розділі 18000000-9 «Одяг, взуття, сумки та аксесуари». В цьому розділі є категорії 18511000-4 «Коштовне каміння для ювелірних виробів», 18512000 1 «Монети та медалі», 18513000-8 «Ювелірні вироби», які містять також групи товарів відповідно до видів коштовного каміння (діаманти, рубіни, смарагди та ін.) та інших матеріалів (вироби із золота, срібла, інших благородних металів, тощо) [3]. У Державному класифрікаторі ДК 016:2010 ювелірні вироби належать до секції C «Продукція переробної промисловості», їм відповідає група товарів 32.12.1 «Вироби ювелірні та подібні вироби» [2].

Особливість товарознавчої експертизи ювелірних виробів полягає у тому, що методика її проведення повинна базуватись на всебічному дослідженні основних характеристик (споживчих властивостей) ювелірних виробів, що відрізняє їх від інших груп товарів, і складається з таких етапів:

1. Гемологічна експертиза, яка ідентифрікує дорогоцінний камінь. Для цього перевіряють відповідність параметрів каменю технічним умовам, складають опис каменю із зазначенням його назви, властивостей і параметрів. При цьому за наявності ярлика перевіряють відповідність параметрів виробу інформації, яку містить ярлик.

2. Пробірна експертиза, яка визначає наявність пробірного клейма, його справжності та відповідності пробірного клейма фрактичному вмісту дорогощінного металу у виробі.

3. Технологічна експертиза, яку проводять 3 метою визначення відповідності ювелірного виробу вимогам нормативно-технічної документації.

4. Художня експертиза, що проводиться, коли ювелірний виріб не тільки має комерційну цінність, але і є авторським, ексклюзивним або антикварним.
Для здійснення товарознавчої експертизи ювелірних виробів використовують такі методи дослідження:

- органолептичний - при визначенні форми, архітектоніки, кольору виробу, наявності клейм; кольору, форми, прозорості, огранювання вставок, наявності в них включень;

- інструментальний (вимірювальний) - при визначенні геометричних розмірів, маси виробів і вставок, відбитків клейм;

- розрахунковий - 3 використанням форомул, що дозволяє визначити масу і форму огранювання вставки виходячи з її геометричних розмірів;

- експрес-метод, за допомогою якого здійснюеться контроль проби металу;

- вартісний метод дослідження - метод визначення показників якості виробів у вартісних одиницях на відповідний період [4, с. 191-192].

Часто необхідною умовою проведення експертизи ювелірних виробів $є$ збереження їх оригінального стану та вигляду, що виключає порушення їх цілісності. Наприклад, для визначення проби виробу за таких умов використовують детектори, принцип дії яких заснований на вимірюванні електрохімічних потенціалів, що виникають на кордоні металу і підведеного електроліту. Вимірювання проводиться за допомогою спеціального зонда. Електроліт в спеціальному балоні встановлюється всередині зонда і під час робочого процесу в мікродозах подається на зразок. Детектори мають налаштування, що дозволяють швидко та ефрективно ідентифікувати основні ювелірні сплави золота, срібла, платини та паладію. Під час вимірювання не відбувається будь-яке пошкодження зразка. Детектори дозволяють проводити: оперативну ідентифікацію чорних, кольорових і дорогоцінних металів і сплавів; виробничий контроль при виготовленні виробів 3 дорогоцінних металів; аналіз справжності виробів 3 дорогоцінних металів (відхилення складу, тонкі покриття 3 дорогоцінних металів на малоцінних підкладках).

Важливою складовою експертизи ювелірних виробів є дослідження вставок 3 дорогоцінних каменів. Характеристики вставок можуть бути визначені експрес-діагностикою, заснованою на дослідженні морфологічних властивостей, що визначають природу каменю:

- вид огранювання і характер включень 3 використанням лупи 3 десятикратним збільшенням;

- твердість - інструментальним методом за шкалою Мооса;

- лінійні параметри, якщо камені е невіддільною частиною виробу, визначаються за допомогою лупи або мікроскопа 3 поділами, при џьму маса каменю визначається розрахунковим методом за форомулами.

Дослідження справжності вставок також може відбуватись за допомогою детекторів, заснованих на вимірюванні теплопровідності та коефіцієнта відбиття зразків. Вони дозволяють відрізнити кольорові дорогоцінні та напівкоштовні камені, а також алмаз від їх найбільш поширених імітацій, включаючи синтетичний муассаніт. 3 метою повної та більш точної оцінки вставок використовуються рентгеноспектральний, рентгенолюмінесцентний методи й метод оптичної інфрачер- 
воної спектроскопї для визначення елементного складу, які застосовують експерти-гемологи під час проведення комплексної експертизи ювелірних виробів.

Часто експертиза ювелірних виробів вимагає залучення ряду спеціалістів. Дослідження об'єктів, що не мають клейм, при необхідності проводиться комплексно за участю фрахівця 3 дослідження металів і сплавів (та виробів 3 них), що визначає якісний і кількісний вміст дорогоцінного металу в сплаві, експерта-гемолога, який встановлюе найменування i природу вставок. При цьому експерт-товарознавець займається розв'язанням питання про класифрікаційну приналежність об'єктів на підставі висновків експертів про найменування і природу вставок, найменування і зміст дорогоцінного металу та власне товарознавчих досліджень [6, с. 135-137].

У результаті органолептичного аналізу, враховуючи характер зносу і виявлених дефектів визначається знижувальний коефіцієнт, який доцільно застосувати для ощінки відсотка і вартості збитку, нанесеного досліджуваному виробу. Для цього варто використовувати порівняльний метод, а саме порівняння досліджуваного об'єкта та товару-аналога або близького за складом і цінністю. Після визначення вартісної бази оцінки необхідно ощінити величину морального і фрізичного зносу (якщо такий $є$ ), нанесеного ювелірному виробу в процесі використання або під час його виготовлення, з урахуванням найбільш характерних дефректів. Серед них найпоширенішими є:
- потертості та подряпини;

- дефекти різьби на виробах з гвинтовими замками;

- надколи емалі;

- надколи, подряпини, потертості на вставках або їх неякісне закріплення.

Найскладнішим завданням при цьому є визначення природи дефекту (він виник у процесі експлуатації або є наслідком неякісного виготовлення). Для його виконання застосовують метод моделювання [1, с. 257-258].

Висновки. Експертиза ювелірних виробів має ряд особливостей, які зумовлюють ії складний характер. Перш за все це стосується проблем визначення підробок та визнання певних видів природних та синтетичних матеріалів (як сплавів металів, так і штучного каміння) ювелірними виробами чи їх складовими. Окрім того визнання художньої цінності виробу може суттево впливати на його ціну, що ускладнює процес визначення його вартості.

Дослідження ювелірних виробів вимагає застосування широкого спектра методів та інструментів, при цьому, найчастіше, з вимогою збереження оригінального стану виробів. Для підвищення якості висновків експертизи доцільно також залучати експертів та спеціалістів 3 інших суміжних copep, завданням яких $е$ глибший аналіз якісних та кількісних характеристик об'єктів. Важливим фрактором також є необхідність застосування експертного та органолептичного методів дослідження, що підвищуе вплив людського фрактора на проведення та результати експертизи.

\section{Список літератури:}

1. Бандурин Р.А. Методические аспекты товароведческой экспертизы и оценки ювелирных изделий со вставками из драгоценных камей. Вестник Брянского государственного университета. 2015. № 3. С. $257-259$.

2. Державний класифрікатор 016:2010. URL:https://dk16.dovidnyk.info/index.php?rozd=14392 (дата звернення: 01.04.2021).

3. Єдиний закупівельний словник ДК 021:2015. URL: https://dk21.dovidnyk.info/index.php?rozd=185 (дата звернення: 01.04.2021).

4. Кобищан Г.Д. Експертиза ювелірних виробів. Експертні дослідження товарів і послуг. 2020. С. $191-193$.

5. Наказ Міністерства фінансів України «Про затвердження Інструкції про порядок здійснення клеймування ювелірних та побутових виробів з дорогоцінних металів, про проведення випробування та експертиз дорогоцінних металів, виробів з них, вставок дорогоцінного каміння, музейних предметів, які містять дорогоцінні метали та дорогоцінне каміння, відбитків державних пробірних клейм» від 20.10.1999 № 244. Верховна Рада України. URL: https://zakon.rada.gov.ua/laws/show/z0874-99\#Text (дата звернення: 01.04.2021).

6. Селиванов А.А. Методика исследования ювелирных изделий со вставками из облагороженных бриллиантов при производстве судебно-товароведческих експертиз. Теория и практика судебной экспертизы. 2015. № 2(38). C. 135-144.

\section{References:}

1. Bandurin R.A. (2015) Metodicheskie aspekty tovarovedcheskoj jekspertizy i ocenki juvelirnyh izdelij so vstavkami iz dragocennyh kamej [Methodological aspects of commodity expertise and evaluation of jewelry with inserts of precious stones]. Vestnik Brjanskogo gosudarstvennogo universiteta, no. 3, pp. 257-259.

2. Derzhavnyi klasyfikator 016:2010 [State classifier 016: 2010]. URL: https://dk16.dovidnyk.info/index.php?rozd=14392

3. Yedynyi zakupivelnyi slovnyk DK 021:2015 [Unified purchasing dictionary SC 021:2015]. URL: https://dk21.dovidnyk.info/index.php?rozd=185

4. Kobyshchan H.D. (2020) Ekspertyza yuvelirnykh vyrobiv [Jewelry expertise]. Ekspertni doslidzhennia tovariv $i$ posluh, pp. 191-193.

5. Nakaz Ministerstva finansiv Ukrainy «Pro zatverdzhennia Instruktsii pro poriadok zdiisnennia kleimuvannia yuvelirnykh ta pobutovykh vyrobiv $\mathrm{z}$ dorohotsinnykh metaliv, pro provedennia vyprobuvannia ta ekspertyz dorohotsinnykh metaliv, vyrobiv z nykh, vstavok dorohotsinnoho kaminnia, muzeinykh predmetiv, yaki mistiat dorohotsinni metaly i dorohotsinne kaminnia, vidbytkiv derzhavnykh probirnykh kleim» vid 20.10.1999 № 244 [Order of the Ministry of Finance of Ukraine "On approval of instructions on the procedure for branding jewelry and household products made of precious metals, on testing and expertise of precious metals, products made of them, inserts of precious stones, museum items containing precious metals and precious stones, impressions of State assay stamps" dated 20.10.1999 No. 244]. Verkhovna Rada Ukrainy. URL: https://zakon.rada.gov.ua/ laws/show/z0874-99\#Text

6. Selivanov A.A. (2015) Metodika issledovanija juvelirnyh izdelij so vstavkami iz oblagorozhennyh brilliantov pri proizvodstve sudebno-tovarovedcheskih ekspertiz [Methods of research of jewelry with inserts of refined diamonds in the production of forensic commodity studies]. Teorija i praktika sudebnoj jekspertizy, no. 2(38), pp. 135-144. 